\title{
Richard Linklater'ın Uyuşuk Filmi ve Antik Yunan Perspektifinden Bir Kamusal Alan Çözümlemesi
}

\author{
Özge Nilay Erbalaban Gürbüz*
}

\section{Özet}

Antik Yunan toplumu, özellikle Atinalılar modern Batı uygarlığının önemsediği değerlerden farklı bir yaşam felsefesine sahiplerdi. Başta aristokratlar ve filozoflar olmak üzere, toplumun ayricaliklı sinıfinın ideal yaşam tanımı özgürlükle sıkı ilişki içindeydi. Özgürlük ise kent devletinin en önemli ayırt edici özelliğiydi. Özgürlük, yurttaşın hem insani hem de yurttaşlık niteliğini yüceltecek düşünsel etkinlikleri gerçekleştirebilmesi için imkân yaratıyordu. Bu nedenle özgürlüğü kısıtlayan üretim ve ekonomiyle ilişkili çalışma etkinlikleri kamusal alanın temel meselesi olmaktan, en azından 'ideal' olmaktan çıkarıldı. Kamusal alan, yurttaşlar için ideal kamusal yaşamı mümkün hale getirecek fikirsel müzakere alanı olarak yorumlandı. Çoğunlukla kamusal alanda yapılan şölenler ya da yönetsel toplantılar bunu gerçekleştiren etkinliklerdi. Kent devletinde kamusal yaşam, yurttaşların birbirleriyle organik iletişim kurduğu, kanaatlerini paylaştığı, politika yapabildikleri gündelik hayat biçimiydi.

Günümüzde ise kamusal yaşam çoğunlukla üretim ve tüketim ilişkilerince biçimlenmiştir, Antik Yunan'da özel alana ait ekonomi ilişkileri çă̆daş kamusal alanın en önemli tartışması haline gelmiştir. Günümüz modern devletlerindeki kamusal yaşam, modern Batı toplumlarının model aldıklarn Antik Yunan'dan tamamen farklı bir dönüşüme uğramıştır. Bu makale Antik Yunan'da benimsenen kamusal yaşam fikrinin Richard Linklater'ın Slacker (Uyuşuk, Richard Linklater, 1990) filminde benzer biçimde yer aldiğını göstermeyi amaçlamaktadır. Öncelikle farkh şekillerde kavramsallaştırılan kamusal alan yaklaşımları ele alınacaktır. Daha sonra boş zaman ve özgürlük açısından Antik Yunan'da site devleti ve kamusal alan arasındaki ilişki ortaya konulacaktır. Makalenin son bölümünde Antik Yunan'da ideal kamusal alan için gerekli görülen boş zamana sahip olma, çalışma ilişkilerinden azade olma, çalışma etkinliğinin hor görüsü ve kamusal yaşamla ilgili fikir üretme gibi ögeler yoluyla Uyuşuk filmi çözümlenecektir.

Anahtar Kelimeler: Uyuşuk Filmi, Richard Linklater, Kamusal Alan, Antik Yunan'da Kamusal Alan, Çalışma Etkinliğinin Eleştirisi, Boş Zaman.

ORCID ID : https://orcid.org/0000-0003-4199-3507

E-mail : nilayerbalaban@hotmail.com

DOI: 10.31122/ sinefilozofi.423094

Geliş Tarihi - Recieved: 12.05.2018

Kabul Tarihi - Accepted: 12.11.2018 


\title{
Richard Linklater's Slacker Film and a Public Space Analysis from Ancient Greek Perspective
}

\author{
Özge Nilay Erbalaban Gürbüz*
}

\begin{abstract}
The ancient Greek society, especially the Athenians, had a philosophy of life that was exactly the opposite of modern Western civilization. The ideal life definition of the privileged class of the society, especially the aristocrats and philosophers, was closely related to freedom. Freedom was the most important commodity of the city state. Freedom enabled citizens to realize intellectual activities that would elevate the quality of both humanity and citizenship. For this reason, work activities related to production and economics, which restrict freedom, have been removed from public sphere at least as 'ideal' and main subject of daily life. 'Ideal' was the production of thought and philosophy. Festivals or administrative meetings, mostly held on the public arena, were activities that did this. Public spaces in the city state were seen as a goal for citizens to organically communicate with each other.

Today, public life is mostly shaped by the relations of production and consumption. In Ancient Greek, the economic relations of the private sphere have become the most important discussion of the contemporary public sphere. Public life in today's modern states has undergone a completely different transformation from the ancient Greek that modern Western societies took as their model. This article aims to show that the idea of public life adopted in Ancient Greek is similarly included in Richard Linklater's Slacker (Richard Linklater, 1990). First of all, public space approaches that are conceptualized in different ways will be discussed. Then, in terms of free time and freedom, the relationship between the site state and the public space will be revealed in Ancient Greek. In the last section of the article, Ancient Greek will be able to analyze Slacker film through items such as having leisure time required for the ideal public space, being free from labor relations, working contempt, thinking about public life.
\end{abstract}

Keywords: Slacker, Richard Linklater, Public Space, Public Space In Ancient Greek, Criticism of Working, Public Space in Slacker, Spare Time.

ORCID ID : https:/ / orcid.org/0000-0003-4199-3507

E-mail : nilayerbalaban@hotmail.com

DOI: $10.31122 /$ sinefilozofi.423094

Recieved - Gelis Tarihi: 12.05.2018

Accepted - Kabul Tarihi: 12.11.2018 


\section{Giriş}

XVIII. yüzyılda burjuva sınıfının iktisadi konumunun garanti altına alınması siyasi ve hukuki olarak özerkleştirilmiş, şeffaf ve denetlenebilir bir devlet mekanizmasını gerektirmekteydi. Bu bakımdan yurttaşların siyasi, hukuki ve kültürel alanlar üzerine fikirlerini müzakere ettikleri ve bunu iktidarı denetleme mekanizması olarak kullandıkları bir kamusal alan ortaya çıktı. Dernekler, gazeteler, kulüpler ve benzeri araçlar yoluyla sivil yurttaşlar toplumsal yaşamı etkileyen resmi kurumlar ve onların bağlı olduğu yasalar ve uygulamalar hakkındaki görüşlerini paylaşabiliyor ve bir kamuoyu oluşturabiliyordu. Aslında Antik Yunan'da da kamusal yaşamın biçimlendirilmesine yön verecek fikirleri müzakere etmek anlamında kamusal alan M.Ö. V. yüzyılda mevcuttu. Ancak modern Batı siyasi tarihi içinde oluşumu bu dönemde başladı. Kamusal alanı kavramsallaştırma ise ilk olarak XX. yüzyılın ikinci yarısında Frankfurt Okulu geleneğinden Jürgen Habermas tarafından yapıldı.

Habermas, burjuva liberal kamusunun oluşumunu tarihsel bir incelemeile yapmaktadır ve bunu araştırmasında açık bir biçimde belirtmektedir (Habermas, 2017:11). Bu burjuva liberal kamusal alan burjuvazinin önceleri özel alanda yaptığı siyasi, kültürel ve edebi tartışmaların bir uzantısı olarak doğmuş olsa da Habermas'a göre kesin bir biçimde özel alandan ayrı olarak kavramsallaştırılır. Aleniyet durumu yani herkesçe görülebilir açık bir alan olması önemlidir. Herkese açık olan bu kamusal alan sivillerin belli bir kamuoyu yaratmak için oluşturdukları alandır (Habermas, 2004: 95). Habermas'ın özel alanı kamusal alandan keskin bir biçimde ayırmasına Nancy Frazer tarafından ikinci dalga feminizm örneği ile karşı çıkılmıştır. Frazer, özel alandaki ataerkil şiddeti ve cinsiyetler arası asimetrik ilişkiyi kamuoyu yaratacak biçimde tartışan feministlerin, özel ve kamusal alan ayrımını ortadan kaldırdığını ifade eder (Frazer, 2004: 118).

Kamusal alanın kavramsallaştııılmasında farklı yaklaşımlar söz konusudur. Jeff Weintraub kamusal alanın kavramsallaştırılmasındaki yaklaşımları dört modele ayırır (Weintraub'dan Aktaran Özbek, 2004: 44). Buna göre kamusal alanın kavramsallaştırılması liberal ekonomiye, cumhuriyetçi erdeme, toplumsal ilişkilere ve feminist modele göre (Özbek, 2004: 44-46) şekillenmektedir. Habermas'ın burjuva sınıfını merkeze aldığı kamusal alan kavramsallaştırması liberal model yaklaşımına dâhil edilebilir. Cumhuriyetçi erdem modelinde kamusal alan Antik Yunan örneğinde olduğu gibi politikayı ve fikri müzakereleri yurttaşlıkla ilişkilendirmektedir. Bu kamusal alan kavramsallaştırmasında ekonomiyle ilgili ilişkiler özel alana aittir. Bu modele ilerleyen bölümlerde dönülecektir. Feminist model yukarıda da değinildiği gibi özel alanı kamusal alandan ayırmaz ve toplumsal cinsiyet rollerinin şekillenmesinde görüldüğü gibi egemen iktidarın baskıladığı grupların kamusunu da tartışır. Bu doğrultuda bir başka kamusal alan kavramsallaştırması Oskar Negt ve Alexander Kluge' nin proleter kamusal alanıdır.

Negt ve Kluge, Habermas' in burjuva kamusunun oluşumunda değindiği ancak tartışma dışı tuttuğu (Habermas, 2017: 11) pleb kamusallık içinden, üretim ilişkilerine odaklanarak proleter kamusal alanı incelemişlerdir. Negt ve Kluge burjuva kamusunun egemenliği altında proletaryanın kendi kamusunu yaratmasındaki güçlüklere odaklanır ve proleter kamunun tam da ona karşıt bir biçimde ve kendi dinamiklerini oluşturduğunu iddia eder (Negt ve Kluge, 2004:133-136). Negt ve Kluge' nin ifadesiyle;

"bizim mesele ettiğimiz alan burjuva kamusal alanının bir çeşidi olmayıp, tam da tersine tarihte kurulmuş ama kamusal alan teriminin parametreleri içine alınmamış olan, tamamıla ayrı, 
bütünlüklü bir toplumsal bağlam kavramsallaştırmasıdır. Böylece grevdeki bir işletme ya da işgal edilmiş bir fabrika, pleb kamusal alanının bir çeşidi olarak değil, üretim sürecinde temellenen bir kamusal alan kavrayışının öz çekirdeği olarak anlaşılmalıdır" (Negt ve Kluge, 2004: 134).

Kamusal alanın kavramsallaştırılmasıyla ilgili bakış açısı, zenginliği de göstermektedir ki toplumsal bir yapı içinde tek ve bütünlüklü bir kamusal alandan bahsetmek mümkün değildir. Toplumsal yapı içinde hemiktidar tarafından yukarıdan aşağıya doğru biçimlendirilen hem de madunlar tarafından ya da etnik, kültürel, politik, ekonomik v.b. kimlikleri nedeniyle periferide kalmışlar tarafından oluşturulan kamusal alanlar bulunmaktadır. Öte yandan birbirinden farklı olmalarına rağmen bu kamuların bazı ortak özellikleri de vardır. Örneğin her bir kamusallık mutlak surette belirli konular etrafında fikri müzakere coğrafyası oluşturur. Habermas (2004: 95), “özel bireylerin kamusal bir gövde oluşturarak toplandıkları her konuşma durumunda, kamusal alanın bir parçası varlık kazanmış olur" demektedir. Ayrıca her bir kamusallık feminist ya da LGBTİ hareketinde olduğu gibi hakkında bir kanaat geliştirmek ya da bir kamuoyu oluşturmak istedikleri konuyu özel alanın dişında, herkesin haberdar olabileceği görünürlükte tartışmaktadır. Habermas'ın 'kamusal gövde oluşturan her konuşma'nın kamusal alanı oluşturduğu saptaması uyarınca da; hayvan haklarından kentin toplumsal mimarisine, göçmenlerin çalışma ilişkilerinden sürdürülebilir enerji kaynaklarına kadar pek çok konu hakkında kamusal bir alan oluşturulabilir. Diğer bir deyişle 'kamusal yaşam'la ilgili her olgu kamusal alanın oluşturulmasına neden olabilir.

Habermas ve Richard Senett'e göre kamusal alan çağdaş toplumlarda ciddi biçimde dönüşüme uğramıştır (Habermas, 2017 ve Senett, 2002). Habermas, iktisadi belirlenim altındaki kapitalizmin, liberal burjuva kamusal alanın işlevselliğini yok ettiğini, kamunun 'özel çıkarları' onaylatmak üzere ikna edilmesi gereken bir gruba dönüştürüldüğünü ifade eder (Habermas, 2004: 101). Senett de özel alana ait olguların kamusal alanı ihlal etmesiyle özel ve kamusal ayrımının ortadan kalktığını sosyal psikoloji disiplini üzerinden açıklar. Senett'e (2002: 36) göre, XVIII. yüzyıldan itibaren “kamusal ve özel alana dair fikirlerde temel bir değişim belirir." Özel alanın XVIII. yüzyıldan itibaren burjuva sınıfının idealize ettiği bir yaşama dönüştürüldügüüü (Senett, 2002: 37) kişisele ait vurgunun öne çıarılmasıyla kamunun yitip gittiğini (Senett, 2002: 336) ifade eder. Her iki araştırmacı da kuramını özel ve kamusal alan arasında Antik Yunan'da hâsıl olan ayrımın izini sürerek oluşturur. Habermas da kısmi bir biçimde, Senett de ise neredeyse kuramının bütünü 'özel' in kamusalı ilhak etmesi sonucu kamusal alanın krize girmesi üzerinedir.

Bu makalede kökleri Antik Yunan'a dayanan Cumhuriyetçi erdem modeline göre kamusal alanın yapısal bir değişime uğradığı bir veri olarak kabul edilmektedir. Buradan hareketle Uyuşuk (Richard Linklater, 1991) filminde kamusal yaşamin görünümünün çözümlenişinde Antik Yunan'ın kamusal alanı bir model oluşturur. Meral Özbek kamusal alanın iki anlam içerdiğini ifadeeder (Özbek, 2002: 40). İlki toplumsal yaşamla ilgili fikri müzakerelerin yeşerdiği kamusal mekânlar, ikincisi ideal kamusal alan fikridir (Özbek, 2002: 40). Uyuşuk filminin neredeyse tamamı kamusal alanda geçer. Film karakterleri ise içinde yaşadığı evrene ve toplumsal yaşama dair fikirleri birbirleriyle paylaşır. Bu kişiler Antik Yunan'daki kamusal alana uygun bir biçimde düşünsel etkinlikleriyle kamusal varlık kurarlar. Onların, Antik Yunan filozoflarının belirttiği gibi evren hakkında düşünce üretmelerine neden olan özgür zamanları zorunluluklardan azade oluşlarıyla ilişkilidir. Antik Yunan'ın agorasından modern dünyaya gönderilmiş gibidirler. Antik Yunan'daki yurttaşlardan farkları ayrıcalıklı bir sınıfın üyesi 
olmamalarıdır. Aksine pek çok karakter çağdaş yaşamın 'ötekisi' olarak görülebilir. Onların toplumun sıradan çoğunluğunun dışında yer almasından hareketle oluşturdukları kamusal alanı egemen kamusal alana karşıt bir kamusal alan olarak değerlendirmek mümkündür. Yine de bu karşıt kamusal alan Negt ve Kluge'nin proleter kamusal alan kuramında değindikleri gibi bir karşıt kamusal kavramsallaştırmasına benzemez. Çünkü Negt ve Kluge'nin proleter kamusal alanı üretim ilişkilerine odaklanırken özel alanı da üretim ilişkilerinin bir parçası gibi görür. Oysa Antik Yunan'daki kamusal alan anlayışında üretim ve ekonomi ilişkileriyle ilgili konular kesin bir biçimde kamusal alanın dişında tutulmuştur. Üstelik filmdeki karakterler de çalışma ve ekonomi konularında Antik Yunan'da ayrıcalıklı sınıfın üyelerinin gösterdiği gibi hor görü tepkisine sahiptir. Filmin bu perspektifte çözümüne geçmeden önce aşağıda Antik Yunan'da kamusal alanla ilgili anlayışın kökleri hakkında bilgi verilecektir.

\section{Antik Yunan Toplumunda Kamusal Alandan Dişlanan Ekonomi ve Çalışma}

Antik Yunan' da boş zamanın yerini (scholé'nin yerine ascholia) boş zamanın yokluğu aldığında özgürlükten kölelik sınırına geçilmiş kabul edilir (Ranciére, 2013: 25). Çünkü scholé kişiye Antik Yunan'ın ruhunu geliştirme ve sürdürme için imkân yaratır. Oysa ascholia durumunda kişi yalnızca temel ihtiyaçlarını giderme eğiliminde yaşamak zorundadır ve bu onun özgürlügüünü ortadan kaldırır. Nedir bu Antik Yunan ruhu? Bu ruh özellikle M.Ö. V. yüzyılda gelişen site-devletine yani Polise yüklenen değerlerle ilişkilidir. Aşağıda ayrıntılandırılacak Platon'un ve Aristoteles'in günümüze kalan metinlerinden, site-devletin Antik Yunan için ontolojik öneme sahip olduğu sonucuna varmak mümkündür. Bu yaklaşım sitenin iyiliğinin yurttaşın iyiliğinin temel dayanağı olduğu sonucunu doğurmuştur. Site devleti Antik Yunan için bir ilkedir. İyi yaşamanın, insanca yaşamanın ilkesidir. Bu nedenle sitenin iyi yönetimini sağlamak için politik faaliyetlerde bulunmak yurttaşın temel amacıdır. $\mathrm{Bu}$ ise özgürlükle ilintilidir. Sadece özgür yurttaş politik faaliyetlerde bulunma hakkına sahiptir. Çünkü ancak özgür yurttaş hem site hem de yurttaş için iyinin 'ne' ve 'nasıl' olması gerektiğini düşünebilmesine imkân veren zorunluluklardan kurtulmuştur. Özgürlüğün karşısında her türlü bağlayıcılığa yol açan zorunluluklar bulunmaktadır. Çalışma faaliyetleri de bu zorunluluklardan biri kabul edildiğinden, kamusal alanın ideal etkinlikleri olmaktan çıkarılmıştır.

H. Applebaum The Concept of Work: Ancient, Medieval, and Modern (1992) eserinde Homeric toplumun, yani Homeros'un metinlerinde anlatılan Yunan toplumunun çeşitli sınıflara ayrıldığını ifade eder. Bu sınıfların en üstünde olan soylular çoğunlukla kökleri atalara ya da Tanrılara dayalı, toprak parçasına, kölelere ve zanaatkârlara sahip kişiler olarak tanımlanır. Sınıflı bir toplumsal yapıda soylularla tamamen zıt olan diğer sınıf ise thetelerdir. (Applebaum, 1992: 3-7). Theteler, Hades'te Aşil'in kölelerden bile daha aşağ1 gördüğü bir sınıftır. Thetelerin kendilerine ait tek mülkleri temel ihtiyaçlarını karşılamak için kiralamak ya da satmak zorunda oldukları çalışma güçleridir. Applebaum, Homerik toplumda Tanrılar soyundan geldiğine inanılan soylular ve thetelerin ortak bir özelliğe sahip olduğunu yazar. Bu ortak özellik her ikisinin de elleriyle çalışmasıdır (Applebaum, 1992: 8).

Catharine Lis de zahmetli çalışmak anlamına gelen 'ponos' sözcüğüne olumlu bir niteliğin yüklendiğini ifade eder. Savaşçlara ait bir değer olan fiziksel dayanıklılıkla ponos arasında bir ilişki kurulduğunu açıklar (Lis, 2009: 34). Maurice Balme de Homeros'un metinlerinde demiourgoilerin yani toplumun çeşitli ihtiyaçlarını karşılamak amacıyla çalışan doktor, şarkıcı gibi kişilerin mesleklerinin Tanrılar tarafından desteklendiği fikrinin yer aldığını 
ifade etmektedir (Balme, 1984: 142). Balme bu metinlerde "doktorların Paion, şarkıcıların Musalar, falcıların Apollo tarafından eğitildiğine" (Balme, 1984: 142) dair görüşlerin yer aldığını ekler. Homeros'tan sonra en önemli şairlerden Hesiodos'un İşler ve Günler (2014) kitabında da çalışmayla ilgili kavramsal bazı düşünceler bulunmaktadır. Hesiodos M.Ö. VIII. yüzyılda yazdığı bu eserde daha sonra Platon'da da vurgulanan insanları soy bakımından farklı niteliklere göre ayırmaktadır. Ancak Hesiodos'un sınıflandırması kronolojik bir dizge halindedir. Buna göre ilk soy altındandır ve en mutlu insan soyudur. Kendisinin de içinde olduğu 'demir' bu kronolojiye göre Zeus'un yarattığ beşinci ve en mutsuz soylardan biridir (Hesiodos, 2014: 13-22). Bu soy Zeus'un Prometheus'a öfkesi sonucu eziyet çekmektedir. Prometheus Tanrılardan ateşi insanoğlu için çalmış ve yasak olanı yapmıştır. Zeus da ceza olarak Pandora'yı elinde bir kutuyla insanlara göndermiş ve insanlardan bütün gıda maddelerini gizlemiştir. Daha önce çalışmak zorunda olmayan mutlu insanlar bu kutuyu açtığında türlü sıkıntılarla karşılaşmıştır. Bunlardan biri de 'çalışmaktır'. Bu nedenle Hesiodos kendi soyundan kişilere "senin doğanda çalışmak var" (Hesiodos, 2014: 28) demiştir.

Hem Homeros'un hem de Hesiodos'un anlatılarında M.Ö. VIII. yüzyıla kadar Antik Yunan toplumunda çalışmayla ilgili olumsuz görüşlerin olmadığını çıkarmak mümkündür. M. Balme de Antik Yunan'ın günlük yaşamından çeşitli örneklerle çalışma olgusunun diğer etkinlikler kadar desteklendiğini göstermiştir. Bu noktada M.Ö. VI. yüzyılda yaşamış Thales ve M.Ö. V. yüzyılda yaşamış Sokrates gibi bazı filozofların da çalışma olgusuna Aristoteles ve Platon'dan farklı yaklaştığına kanitlayıcı örnekler verir. Balme, Thales'ten “zengin olsan bile tembellik etme" (Aktaran Balme, 1984: 143) öğüdünü aktarır ve Sokrates'in çiftçilik konusundaki olumlu düşüncelerine yer verir (Balme, 1984: 146). Bununla birlikte Balme'nin makalesi Antik Yunan'da çalışma olgusuyla ilgili düşünceleri etkileyen kölelerin varlığ hakkında da pek çok örnek gösterir. Ve Antik Yunan' da kölelerin sayısının yurttaşların hayatını çalışma dışı etkinliklere adamaya imkân verecek boyutta olmadığı iddiasını taşır. Euripides' in Elektra adlı metininde, Elektra'nın bütün el işlerini kendisinin yaptığını ve hiçbir kölesinin olmadığını örnekler (Balme, 1984: 145). M. Balme'in bütün makalesi Antik Yunan'da çalışma olgusunun gündelik hayattaki ihtiyaçların giderilmesi aşamasında olumlandığı tezi üzerine kurulmuştur. Çalışma olgusunun Antik Yunan'da da Protestan çalışma etiğinde olduğu gibi 'erdem' olarak kabul edildiğine dair bir tarih okuması yapmıştır. Burada 'ihtiyaç' olgusu Antik Yunan düşüncesinde çalışma etkinliği üzerine felsefi boyutları olan fikirlerin üretilmesine imkân veren anahtar kavramdır. Ve kuramsal olarak çalışma etkinliğine yöneltilen olumsuz eleştirilerin nedenlerini ortaya koymaktadır.

Hannah Arendt çalışma konusunda Antik Yunan'da yukarıda da yer verilen fikirlerin M.Ö. V. yüzyılla birlikte değişmeye başladığını ifade eder (Arendt, 2006: 135). Bunun sebebi Polis adı verilen site-devletinin büyümesi ve yurttaşların devlet işlerine daha fazla önem göstermesi ihtiyacının ortaya çıkmasıdır (Arendt, 2006: 135). Burada polisin özellikle bir Atinalı için anlamını açıklamak gerekir. Çünkü kamusal alana dair en önemli ihtiyaç yani 'iyi yönetme' ve 'iyi yaşama' ihtiyacı bu olguyla sıkı ilişki içindedir.

Polis içinde yurttaşların yaşadığı coğrafi bir yönetim biçiminden öte, barbarlar ve özgür insanlar arasındaki nitelikleri ortaya koyan zihinsel bir olgudur. Değerlerin, fikirlerin, ahlaki yaklaşımların, iyi ve anlamlı yaşamın kaynağıdır (Sylvester, 1999: 4). Aristoteles sitedevletin kendi örgütsel yeterliliğine erişip, “iyi yaşamın” kaynağı olduğunu ve bireyden önce geldiğini ifade eder (Aristoteles, 1990: 9-10). Buna site devletinden olmayan kişinin insanlığın 
en altında ya da en üstünde olduğunu ekler (Aristoteles, 1990: 9). Egon Friedell de polisin Antik Yunan yurttaşı için anlamını şu şekilde ifade eder

\begin{abstract}
"kapalı ve başına buyruk bir polis vatandaş için her şey demekti (...) devlet işlerinde yer almak, vatandaşlık haklarından yararlanmak demektir; fakat basitçe 'yaşamak' anlamına da gelir, çünkü polis dışında bir yaşam düşünülemezdi (...) Her türlü varoluş salt onunla anlam kazanır, insani değerler onunla tamamlanır. Her kültürün, her etiğin, hatta her dinin taşıyıcısı odur (...) Polis taşınabilirdi; vatandaşlar nereye yerleşirse, orada yeniden oluşabilirdi, çünkü zamanın ve mekânın ötesinde bir idea'ydı o" (Friedell, 1999: 108).
\end{abstract}

Polisin böylesine değer atfedilen bir olgu olması ihtiyaçların niteliğini iki şekilde belirler. İlkinin Aristoteles'in insan "siyasal bir hayvandır" (Aristoteles, 1990: 9) saptamasiyla ilişkili olduğunu çıkarsamak mümkündür. Buna göre polis, devlet işleriyle ilgili yönetsel ihtiyaçları ve ideal bir toplumsal yaşamın 'nasıl' olması gerektiğiyle ilgili fikri müzakereleri kamusal alanın en temel sorunu olarak görür. Dolayısıyla Antik Yunan'da kamusal alan ve kamusal yaşamla ilgili meseleler özel alandan tamamen ayrı konumlandırılır ve önem sırasına göre daha önde yer almaktadır. Arendt "kamu alanının karakteri oraya girişine izin verilen etkinliklere göre değişmektedir" (Arendt, 2006: 88) demektedir. Antik Yunan'da da ekonomiyle ilgili etkinlikler modern kamusal yaşamdan farklı olarak kamusal alandaki tartışmalardan tamamen dışlanmıştır. Ekonomi işleri özel alana ait ihtiyaçlardandır ve zaten ekonomi sözcüğü “ev idaresi” (Buğra, 2005: 46) anlamına gelmektedir.

$\mathrm{Bu}$ yaklaşım poliste yaşayan özgür yurttaşların hangi etkinlikleri 'değer' olarak tanımladığında belirgin bir yol haritası sunmuştur. Özellikle Atinalılar için site-devleti insan olmanın sınırlarını da belirlediğinden bu site-devletin yönetimiyle ilgili meseleler tüm ihtiyaçların üstünde görülmüştür. Öte yandan bu 'değerler'in oluşturulması çoğu zaman toplumdaki en üst sınıf kabul edilen aristokratlar ve soylu filozofların etkisi altındadır. Charles Sylvester Antik Yunan'da özgür yurttaşlarla aynı demokratik haklara sahip olan aristokratların hoşnutsuzluklarını ifade eder (Sylvester, 1999: 6). Ve aristokratların kendilerini sıradan özgür yurttaştan ayırmak için eleutherios paideia kavramını kullandıkları iddiasını taşır. Özgürlük anlamına gelen 'eleutheria' kelimesinden türetilen Eleutherios paideia "boş zaman, ağırbaşlılık ve entelektüel uğraşlarla yakından ilintili; dostlara ve kamu hizmetine adanmış aristokratik bir kavramdır. Eğitimsiz ve yetenekten yoksun beden gücüne dayalı işçilerin tamamen zıttı" dır (Sylvester, 1999: 6). Böylece boş zamana sahip olmayan yurttaş ile hem özgür hem de boş zamana sahip aristokrasi arasında, yurttaşın niteliğini etkileyen bir sınır çizilmiştir. Özgürlük, yaşamın sürdürülmesi için başkasının boyunduruğu altında olmamaktan daha geniş bir kavramdır aristokrasi için. Özgür olmak boş zamana sahip olmayı engelleyen zorunlu ekonomik etkinliklerden azade olmaktır. Boş zamana sahip olmak kamu işleriyle ve entelektüel uğraşlarla ilgilenmeye imkân sunacağından hem kişinin kendisini geliştirmesini hem de devletin iyi yönetilmesini sağlayacaktır. Aristokrasinin iyi yurttaş olmayı devlet işlerine zaman ayırabilecek boş zamana sahip olmakla ilişkilendirmesi, ekonomi etkinliklerinin kamusal alanda tartışma dışı bırakılmasının nedenlerinden biri olarak yorumlanabilir.

Aristokratların kendilerini sıradan özgür yurttaştan ayıran önemli niteliklerden biri olarak 'boş zaman'a sahip olma ayrıcalığı, M.Ö. VI. ve V. yüzyıllarda klasik felsefenin iki büyük ismi Platon ve Aristoteles'te de önemli bir nitelik olarak değerlendirilmiştir. Filozoflar tabiattan sahip olduğu yetenekler (Gürbüz, 2014: 199-202) nedeniyle kendi özgürlüklerini 
kısıtlayan çalışma faaliyetlerinden uzak durmalıdır. Çünkü onlar doğuştan "bilime düşkün" (Platon, 2003: 158), "varlığ1 bütünüyle seven" (Platon, 2003: 158), "ruhun zevkini arayan" (Platon, 2003: 158), “Tanrı ve insan işlerini bütünlüğüyle kavramaya uğraşan"(Platon, 2003: 158), "düşünceleri yücelere yükselen" (Platon, 2003: 159), kolay öğrenip aklında tutabilen (Platon, 2003: 159) kişiler olduğundan, sıradan halkın tabi olduğu yasalardan ve işlerden uzak duracaktır (Gürbüz, 2014: 198-199). Onların görevi devleti yönetmektir. Çünkü "filozoflar devleti ele geçirmedikçe, ne devletin, ne de yurttaşların dertleri bitmez" (Platon, 2003: 172). $\mathrm{Bu}$ nedenle boş zamanı ortadan kaldıran çalışma etkinliği filozoflar için küçümsenmiştir. D. Méda da Antik Yunan felsefesinde çalışmaya yönelik hor görüyü yorumlarken şu ifadeleri kullanir:

\begin{abstract}
Yaşamın saf maddi yeniden-üretimiyle ilgili işler özü gereği kölecedir, çünkü bizi zorunluluğa bağlar. İçimizdeki en insani yanı geliştirmek, tanrısal olana yaklaşmak istersek, bu görevlerden uzaklaşmamız ve bunlar, aslında insan olmayan kölelere bırakmamız gerekir. Gerçekten insan olmak tamamen başka şey olacaktır: Felsefe yapmak, güzel olanı seyre dalmak, politik faaliyet yürütmek, her durumda aklını kullanmak; çünkü insan akıllı bir varlıktır (Méda, 2012: 42-43).
\end{abstract}

Thomson da M.Ö. V. yüzyılda bedeni yoran mesleklere yönelik hor görüye sahip bir sınıf doğduğunu söyler (Thomson, 1997: 226). O halde M.Ö. V. yüzyılda Antik Yunan' da ister aristokratik ister felsefi açıdan olsun en azından 'ideal' etkinlik bağlamında 'çalışma' kamusal hayatta bugünkü anlamından farklı değerlere sahip olmuştur. Çalışma, özgürlügün ve düşünmeninönündeengeldir. Çünkü çalışan kişi öncelikle kendiözgürlüğünü para karşılığında bir başka kişiye devretmiştir ki Antik Yunan toplumu için özgürlük en önemli erdemlerden biridir. Öte yandan çalışan kişi Platon'un insan arzularının içinde en erdemli olarak kabul ettiği bilme arzusundan uzaklaşmış ve böylece en iyi yaşama biçiminden de uzaklaşmıştır (Platon, 2003: 247). Eğer Aristoteles'in kölelik üzerine düşünceleri hatırlanacak olursa, filozofun köleliği haklı ve yerinde bulmasının arkasında da bu nedenin olduğu görülecektir. Aristoteles, köleyi Atinalı bir yurttaşın asli faaliyetlerini yapmasına yani düşünceye dayalı etkinlikleri yerine getirmesine imkan tanıyan bir araç olarak görür (Aristoteles, 1990: 12). Üstelik aynı metinde Aristoteles yaşamın üretim değil eylem olduğunu vurgular (Aristoteles, 1990: 12). Hem Platon hem Aristoteles için iyi ve erdemli yaşam kişiyi özgür düşünmekten, bilgece yaşamaktan uzaklaştıran çalışma faaliyetlerinin dışlandığı, düşünme etkinliklerine yer verilen yaşamdır.

Modern toplumlardaki kamusal yaşam ise Antik Yunan'ın kamusal yaşam anlayışına tamamen terstir. Boş zaman ve özgürlük yerine iktisat, üretim ve çalışma olgusu getirilmiştir. Özel alana ait bütün meseleler "kolektifleştirilmiştir"(Arendt, 2006: 71). İnsani gelişim entelektüel uğraşlar yerine ekonomik üretimin verileriyle eş değer tutulmuştur. Bu noktada ticari filmler modern dünyaya ait bu dünya görüşünü çoğu örnekte sorgulamadan tekrar etmektedir. Filmlerde entelektüel etkinliklerden ziyade ekonomik üretime adanmış yaşamlar idealize edilmektedir. Oysa felsefi düşünceye yaslanan filmlerde 'ideal' olan sorgulanır ve yeni düşüncelerin gelişmesine yer açar. Üstelik S. Öztürk'ün de belirtmiş olduğu gibi filmler Antik Yunan'a özgü kamusal alan ve felsefe ilişkisini yeniden kamusal alana yöneltebilir (Öztürk, 2018: 8). Çünkü filmler, özellikle herhangi bir sorunsal üzerine çekilen filmler, o sorunsalı kamusal alanda görünür hale getirmeye, tartışmaya açmaya, kanaat geliştirmeye ve hatta kamuoyu oluşturmaya aracılık edebilirler. Dünya sinema tarihinde siyasal bir kamuoyu oluşturmaya doğrudan neden olmuş pek çok film bulunmaktadır. Öte yandan filmlerde 
mevcut kamusal yaşamdan farklı kamusal yaşam örnekleri kurulabilir ve seyircinin bu kamusal yaşam üzerine düşünmesi motive edilebilir. Kurmaca, gerçekte olanla olması gereken arasındaki boşlukları, benzerlikleri ya da farklılıkları açığa çıkarabilir. Aşağıda R. Linklater'ın Uyuşuk filmi çözümlenirken Antik Yunan'da kamusal alanı oluşturan fikri müzakere, felsefi yaratıcılık ve çalışma etkinliklerinin hor görüsü gibi kavramlardan yola çıkılmaktadır. İzleyici ister sinema v.b. gibi kamusal alanda ister özel alanında filmi izleme fırsatı yakalasın, filmde sokak, kafe, kitabevi, park gibi kamusal alanlarda birbiriyle evren, toplumsal yaşam, bilim, sanat ve felsefe gibi konularda müzakere eden karakterler yoluyla film dünyası içinde akışkan bir biçimde aktarılan bir kamusal alan ve kamusal yaşam örneğini fikirsel düzeyde deneyimlemeye yönlendirilir.

\section{Uyuşuk Filmi ve Antik Yunan Perspektifinden Bir Kamusal Alan}

Richard Linklater'ın Uyuşuk'u Amerikan Bağımsız Sinemasının doksanlı yıllarında, klasik anlatı sinemasından farklı olarak merkez bir hikâye, hikâyeyi devindiren ana karakterler ve giriş-gelişme-sonuç ögeleri kullanılmadan çekilmiş bir filmdir. Bu nedenle filmin belirli bir olay öyküsü yoktur. Filmin bütünü bir günlük zaman aralığında farklı insanların birbirleriyle yaptıkları yirmi beş karşılaşmadan oluşmaktadır. Her bir karşılaşma karakterlerin evren, toplumsal yaşam, edebiyat, kitle iletişimi, sanat gibi konular hakkındaki fikri müzakerelerini yansıtan sahnelerden oluşmaktadır. Ve bu sahneler özel alan olarak tarif edilen 'hane'nin dışında, kamusal alanda bulunan sokak, mahalle, kafe, sinema gibi mekânlarda çekilmiştir. Filmdeki karakterler ise kendilerini "takılmak" olarak adlandırdıkları durumun içinde tarif etmektedirler. Tüm bu nedenler filmdeki kamusal yaşamı Antik Yunan perspektifinden incelemeye zemin oluşturmaktadir.

Filmdeki karakterlerin ana dillerinde "hangout" olarak kendilerini ifade ettikleri durum Türkçeye "belirli yerlerde ve/veya belirli kişilerle uzun zaman geçirmek" (Hangout, Tarihsiz, Cambridge Dictionary Online) olarak çevrilmektedir. Fakat burada filmin anlamsal bütünlüğü düşünüldügüunde kelimeyi ‘sabit bir işte çalışmadığından, sahip olduğu boş zaman içinde gündelik hayat üzerine belirli kanaatler geliştiren ve bu kanaatleri başkalarıyla paylaşan kişilerin günlük hayatlarını geçirme durumları' olarak almak mümkündür. Bu yönüyle karakterler Antik Yunan' da demokratik polis devletinin en üstün erdemi olarak kabul ettikleri özgürlük yani 'eleutheria'ya sahiptirler. Öte yandan karakterler demokratik polis devletinin bir diğer erdemi ve yasası olarak 'isēgoria' yani "herkesin aklına geleni özgürce söylemeye eşit hakk1 olması" (Ste.Croix, 2013: 361) bakımından birbirleriyle yaptıkları sohbetlerde tam bir eşitlik halindedirler. Karakterlerin sahip oldukları boş zaman ile fikirsel üretimleri arasındaki ilişki düşünüldüğünde filmin isminin anlamı, kökleri Antik Yunan'da bulunan bir ironi içermektedir. Antik Yunan'da özgürlüğün ön koşulu olarak boş zamana sahip olmakla gezmek ve düşünmek arasında anlamsal ilişki bulunur. Sylvester'ın aktardığı kadarıyla Eleutherios paideianın boş zaman ve entelektüel düşünceyle ilişkilendirilen 'aristokratik' bir kavram olduğuna yukarıda değinilmişti. Çağdaş dünyada Walter Benjamin flaneur kavramına da benzer bir anlamı atfetmiştir: "Flaneur, işi gücü olmayan birinin kişiliğine bürünerek gezinir; böylece insanları birer uzman yapan iş bölümünü de protesto etmiş olur. Bunun yanı sıra insanların iş güç peşinde koşuşturup durmalarını da protesto eder" (Benjamin, 2012: 148) demektedir. Öte yandan Antik Yunan'da düşünmek, fikir üretmek ve sohbet etmek anlamlarına gelen ve İngilizce 'school' (Türkçesi ‘okul') sözcügüüün kökü olan schole`kelimesi böylesi etkinlikler için kullanılmaktadır (Ken, 2014: 286). Antik Yunan'da aylaklığın sohbet 
etmeyi ve düşünmeyi içine alan entelektüel bir etkinlik olduğu da unutulmamalıdır (Friedell, 1999: 203). Bu açıdan film Antik Yunan'da kabul edilen çalışma etkinliğinden azade olmayla aylaklığın yaratıcı düşüncelere imkân veren potansiyelini göstermektedir. Film boyunca "en iyi eserler, en derin düşüncelerin yatağı olan en uzun tembelliklerin çocuğudur" (Dranas, 2000: 46) ifadesinde olduğu gibi, yaratıcı aylaklık fikri tüm karşılaşmaların ortak noktasını oluşturmaktadır. Filmin yönetmeni de filmdeki karakterlerin özellikle çalışma faaliyetleri tarafından ele geçirilmemiş ve kendi yaratıcı uğraşlarına zaman ayırabilen insanlar olarak gösterildiğini söylemektedir (Richard Linklater İle Söyleşi, 25.06.2012, Youtube). Kitap okumak, sinemaya ya da tiyatroya gitmek, gitar çalmak gibi yaratıcı üretkenliğe yönelen bu karakterlerden oluşan film, A.B.D'nin bazı şehirlerinde 'aylaklı̆̆g' özendirici bulunduğu için filmin yasaklanması talep edilmiştir (Richard Linklater İle Söyleşi, 25.06.2012, Youtube).

Film yukarıda da belirtildiği gibi klasik öykü anlatımının dışına çıkarak her bir karşılaşmayı kendi içinde bağımsız bir öykü oluşturacak şekilde sunmaktadır. Bu nedenle bir başlangıcı ve bir sonu yoktur. Karakterlerin durmaksızın yürüyüşleri ve hareketleri kesintisiz bir biçimde akmaktadır. Çerçeveye yürüyerek giren bir oyuncu bir başka oyuncuya yerini bırakıp çerçeveden çıkar. Kamera, sokaklar ve caddeler boyunca bu durmaksızın yürüyen ama bir yere yetişme telaşından uzak insanları takip etmektedir. David Le Breton'un ifadesiyle,

\begin{abstract}
“çağdaş dünya bağlaminda yürümek bir nostalji ya da direniş biçimini akla getirebilir (...) Yaşamın bir yığın önemsiz şeyi konusunda bir temel felsefenin geliştirilmesine elverişli bir etkinliktir, gezgini bir süre kendisi, doğayla ya da başkalarılla ilişkisi hakkında sorular somaya, beklenmedik bir yığın soru üstüne düşünmeye götürür. Aylaklı, acelesi olan insanın hüküm sürdüğü dünyada bir terslik gibi gözükür. Zamanın ve yerin tadını çıarma olan yürüyüş bir kaçış, modernliğe bir naniktir. Çllgin yaşam ritimlerimiz içinde bir kestirme yoldur, mesafe almaya elverişli bir etkinliktir" (Le Breton, 2007: 14).
\end{abstract}

Öte yandan Rob Stone'a göre bu durmaksızın yapılan gezintiler ve bir başlangı̨̧ ve sondan oluşmayan öyküler Richard Linklater'ın sinemasını Gilles Deleuze'ün kuramına yaklaştırmaktadır (Stone, 2013: 73-88). Deleuze için hareket bölünebilir değildir. Hareket durmadan oluş halinde olan şeydir. Deleuze filmler için "kendini yaratmayı hiç bırakmaz; tıpkı niteliksel bir durumun kümesini bir başkasına taşıyormuş gibi, tıpkı bu durumlardan geçen durmak bilmez, saf oluş gibi" (Deleuze, 2014: 22) ifadesini kullanmaktadır. Uyuşuk filminde olduğu gibi hareket, 'oluş' yönüyle kendi gerçekliğini kurmaktadır. Uyuşuk filminin sonuca bağlanmayan ama birbirini etkileyen karşılaşmalarında bir halden bir hale gelmek ya da akışkanlık diyebileceğimiz bu 'oluş' biçimi vardır. Bu durum filmin bütününü oluşturmaktadır. Yönetmen klasik sinema anlatımı olan giriş, gelişme ve sonuç duraklarından oluşan bir yapıyı tercih etmeyerek içerikte yer alan konuları ve karakterleri yaratan düşünceye sadık kalmaktadır. Öte yandan bu anlatım biçimi modern hayatın bütünleyici ve tek merkezden oluşan örgütlenişini de eleştirmektedir. Bu nedenle filmin biçimi de ticari ya da endüstriyel sinemanın majör estetiği yerine minör bir estetikle oluşturulmuştur.

Filmin anlatım biçiminde olduğu gibi filmdeki karakterler de özgündür. Stone'un da ifade ettiği gibi onların aylaklıkları "tembellik değildir ama gelenekçiliğe, tüketim kültürüne ve rekabetçiliğe bir karşı çıkış olarak hayal etmeyi, yansıtmayı, birlikteliği ortaya koyar" (Stone, 2013: 75). Bu nedenle çalışma hayatının ritmine göre belirlenmiş kişilikler tarafından oluşturulmuş kamusal yaşama alternatif bir kamusal yaşam örneği sunarlar. Piyasa toplumuna özgü kamu tarafından hor görülen bu sosyal tipler, çalışma ideolojisi tarafından gündelik hayatın görmezden gelinen ayrıntılarına inerler. 
Bu sosyal tiplerin ilki filmin açılış sahnesinde gösterilmektedir. Sahne takside yolculuk yapmakta olan bir gencin felsefi sorgulamalarını içermektedir. Karakter (yönetmenin kendisidir) yaptığı işten başka hiçbir olaya odaklanmayan taksiciye dünyayla ilgili sorularını durmaksızın anlatmaktadır. Taksicinin son derece kayıtsız durumuyla yolcunun dünyayla ilgili sorgulamalarındaki ciddiyet ve ilgi, çalışma dünyasının araç haline getirdiği bir insan ile çalışma etkinliğinden kurtulmuş bir kişinin dünyayı seyre dalmadaki isteği arasındaki farkı ortaya koymaktadır. Taksici aracını dikkatli bir şekilde sürmekle kendi görevini uygulamaktadır. Ancak en önemli insansal etkinliklerden biri olan 'iletişim' kurma zahmetine girmemekte ve yolcusunun anlattıklarına karşı hiçbir duyarlılık belirtisi göstermemektedir. Bu sahne Antik Yunan perspektifinden boş zamana sahip olan özgür kişi ile çalışan kişi arasındaki fark üzerinden, bu kişilerin hayat hakkında düşünce üretebilme potansiyellerine dikkat çekmektedir. Zaten Antik Yunan'da filozof tüm zorunluluklardan azade olması gereken bir kamusal figür olarak kendini kurar (Gürbüz, 2014: 202). Çalışmanın zorunluluklarından kurtulmak ve belirli bir zamansal düzenlemeye tabi olmamak dünyayı tefekkür etmenin ilk koşuludur. Yolcu, insanların yaptığı seçimlerle faklı hakikatlerin oluşmasına neden olduğundan ve seçmedikleriyle de başka gerçekliklere yol açtığından bahsetmektedir. "Yaptığın her tercih ve verdiğin her karar, yapmamayı seçtiğin şey parçalanır ve kendi gerçekliğini oluşturur"demektedir. Bu alternatif gerçeklikler teorisini Richard Linklater'ın filmlerinde alt metin olarak düşünmek gerekmektedir. Onun sineması verili modern piyasa toplumsallığının dışındaki yaşamları gösterme ve onların felsefesini izleyiciye aktarma amacını taşımaktadır. Bu nedenle sineması metinlerarasılıktan beslenmektedir (Stone, 2013: 2-4). Diğer taraftan filmdeki aylak karakterlerin film boyunca şiirden, edebiyattan, bilimsel çalışmalardan beslenmesi Simmel'in "tembelliğin zirvesi estetik hazdır" (Simmel, 2000: 88) önermesini haklılaştırırken Antik Yunan'a ait değerleri yeniden oluşturur. Çünkü sanat ve estetik gibi zihinsel uğraş gerektiren olgular üzerine düşünmek boş zamana sahip olmayı gerektirir.

Bir diğer sahnede yolcu iner ve indiği yerde bir trafik kazasına tanık olur. Trafik kazası sahnesi bizi bir başka sahneye yönlendirir. Kamera farklı bir karakteri takip ederek bir kafenin içine girer. Kafede kıyafet ve sakallarından herhangi bir kurumsal düzenlemenin içinde yer almadığını anladığımız bir grup genç, edebiyat üzerine tartışmaktadır. Bir başka masadaki karakter bir manifesto yazmaktadır ve yüksek sesle bu manifestonun dört numarasını açıklar:“Numara dört: tüm insan çabasından feragat!” Bu ilke, hem varoluşçu felsefeden hem de yabancılaşmış çalışmanın karşıtı olan kuramlardan beslenmektedir. "İnsan çabasından feragat"la başlayan manifesto dünyanın olduğundan daha kötü bir yere gitmesini, yıkımın kurtuluş olduğunu ve bu nedenle dünyanın bu kültürle devam etmesi için kullanılan çabaların gereksiz olduğunu savunmaktadır. P. Lafargue da Tembellik Hakkı (2014) metninde işçilerin çalışma istek ve çabalarını mevcut düzenin devam etmesine katkı sunması bakımından eleştirmektedir. “Kapitalist uygarlığın hüküm sürdüğü ulusların işçi sınıfları tuhaf bir deliliğin esiri olmuşlar. Kederli insanlığa yüzyıllardır işkence eden bireysel ve toplumsal sefaletler de bu deliliğin peşinden geliyor. Bu delilik, çalışma hakkıdır" (Lafargue, 2014: 9) diyerek işçilere bu sistemi devam ettiren çalışmaya dair istek ve taleplerinden uzaklaşmaları gerektiğini ifade eder. Bu açıdan manifesto mevcut düzenin değerlerinden kopuşu yansitan içeriğiyle dikkat çekmektedir. Ayrıca çalışma fikriyle ilgili bir kanaat kamuoyu oluşturmak üzere dile getirilir. $\mathrm{Bu}$ arada kamera aynı kafenin içinde gezmeye devam etmektedir. Çağdaş bir düşünür olarak flaneur, kameranın gözüyle özdeşlik kurar ve izleyici sanki agorada gerçekleşen bir düşünsel 
sohbetin içine yerleştirilir. Kamera Antik Yunan'ın agorasından XVIII. yüzyıl Paris kamusunun bir bileşkesi olarak kafenin içinde gezmeye devam eder. Bir masada edebi tahminler yapılır ve karakterlerden biri "yaratmamak için gereken muazzam çaba hakkında kim yazdı?" sorusunu diğer arkadaşlarına yöneltir. Ve devam eder "tümüyle pasif olanın saplantılı olması." Bu cümleler manifestodaki düşünceyi sürdürmeyi edebiyat yoluyla devam ettirmektedir. Bu noktada kendisine verilen görevleri israrla reddeden 'Katip Bartleby' karakterini anmak gerekmektedir. Herman Melville Katip Bartleby'yi XIX. yüzyılda yayınlamıştır. Proletarya ve burjuva sınıfının keskin karşıtlıklar içinde olduğu bu dönemde Melville, Lafargue'ın politik bir yöntem olarak düşündüğü 'tembellik hakkını' Bartleby karakteri ile somutlaştırmaktadır. Bartleby, bulunduğu çalışma ofisinin tüm görevlerini yerine getirebilecek niteliklere sahipken kendinden istenilen görevleri 'yapmamayı tercih etmektedir'. BöyleceXVIII. yüzyıldan bu yana bir hakikat gibi görünen işçilerin görevlerine ve patronlarına bağl1lık söylemi yıkılmaktadır. Bartleby kendine yüklenen işleri ‘yapmamayı tercih ederek' özgürlüğünü kazanmıştır. Bülent Diken, Katip Bartleby'inin 'yapmamayı tercih etmesi'ni politik yollarını çeşitlendirmemesi bakımından nihilizm kavramı içinden okumaktadır (Diken, 2011: 164-168). Diken'e göre Bartleby'nin davranışları etkinlik ve edilginlik arasında bir yerde durmaktadır:

\footnotetext{
"hiç şüphe yok ki böyle bir hiçbir şey yapmama politikası güçlü edimler yaratabilir. Ama bunu ancak nihilizmden kurutulabilirse yapabilir. Bu yüzden, her edimin bir edilginlik biçimine, verili iktidar ilişkilerinden bir kopmaya bel bağlamak zorunda olduğu gerçeğine rağmen, etkinlikle edilginlik arasındaki ilişki sınırlandırılmalıdır" (Diken, 2011: 164).
}

Oysa masada sohbet eden gençlerin, sohbet etme etkinliklerinin piyasa toplumu açısından edilginlik olarak değerlendirileceği üzerinden bakıldığında etkinlik ve edilginlik olguları muğlaklaşmaktadır. Bu bağlamda 'yapmamayı tercih etmek' ve 'tümüyle pasif olanın saplantılı olması' nihilizmden çok minör bir politika haline gelmektedir.

Bu kez masadan kalkan kişiyi takip eden kamera yeniden sokaktadır. Uyuşuk filmi yukarıda da andığımız biçimiyle yürüyüşler, telaşsız karşılaşmalar ve gözlemlerden oluşmaktadır. Karakterler hem Antik Yunan'ın filozofları hem de XIX. yüzyıl modern kentinin yarattığı sosyal tip olan ama kentin akıp giden telaşına katılmayan flaneurler gibi şehri gözlemlemektedirler. Bu bağlamda karakterler şehri hızdan uzak bir biçimde gezerken, modern piyasa toplumunun akıcı trafiğini reddetmektedir. Şehrin hızı, kültürün geldiği biçim, bazı karakterlerde, yaşadığı uygarlığa yabancılaşan bireyin komplolara dayalı düşünme biçimi olarak yansımaktadır. Bu karakterlerde Deleuze'ün belirtmiş olduğu gibi “algıların halüsinasyonu altında, hatta düşüncenin sayıklamasının altında daha derin bir şeyler vardır, bir yoğunluk duygusu, yani bir oluş, bir geçiş" (Deleuze, 2009: 30) vardır. Piyasa toplumsallığına ayak uyduran bireylerin sahip olamayacağı düşünme biçimleri bu karakterlerde yeniden yansitılmaktadır. Bu insanların zamansal özgürlükleri onlara ayrıntılar üzerine düşünme imkânı vermektedir. Genel için safsata, boş gevezelik adı altında sohbetten sürgün edilen konular, bu insanların temel meselesi haline gelmektedir. Genel için ayrıntıdan ibaret olan meselelerin minör sanat eserlerinde temel konu haline gelmesi türe özgü bir içeriktir. Herhangi bir zorlamayla kesilmeyen sohbetler, yalnızca başka bir karşılaşmanın yarattığı yeni bir fikir tarafından duraklamaktadır.

Bir başka karşılaşma ile kamera bir evin salonuna geçmektedir. Salondaki üç kişiden ikisi üzerlerindeki günlük kıyafetlerle bir tür el oyunu oynamaktadırlar. Çocuksu bir neşenin göze çarptığı bu kişiler, bir yandan da arkadaşlarının Amerika Birleşik Devletleri'ndeki başkanlık 
seçimleri üzerine olan fikirlerine kulak misafiri olmaktadır. Evin duvarlarında Marx'ın posterlerinin asılması bu karakterlerin popüler siyaset alanına eleştirel bir perspektiften baktığını göstermektedir. Popüler olanın dışına çıkabilecek fikirsel zemine ulaşmak, popüler olanla sıkı bir ilişki içinde olan piyasa toplumsallığının dişına çıkmayla mümkündür. Zorunlu çalışmanın baskısından kurtulan kişiler, piyasa toplumsallığına ait kültürel söylemlerin de dışına çıkmaktadır. Böylece flaneur' ün kenti gezerken kentin değişimini fark edebilmesindeki olumlu yabancılaşma gibi, piyasa toplumunun dışında yer alan karakterler de toplumsal alanın değişimlerini ve gerçeklerini daha açık bir biçimde fark ederler. Ve konuşma ev arkadaşlarından birinin evi terk etmesinin fark edilmesiyle bir başka yöne geçmektedir.

Evi terk eden karakterin arkasında bıraktığı kartpostallar, bir çeşit foto-roman biçiminde aktarılır. Kartpostalların bütününden evi terk eden kişinin kendisi ve hayatıyla ilgili şu notlar okunmaktadır: "Juan Apagato şehirde gezinerek çok zaman harcar. Bir süre üniversiteye gitmeyi denedi ama üniversite çok fazla zaman harcadı. Bu yüzden şimdi çok fazla çalışma gerektirmeyen bir iş arıyor (...) Farklılıkların benzerliklere oranla daha az olduğunu düşünüyor. Her sabah 11 veya 12'de uyanıyor. Kapıdan bakıyor, kitap okuyor, dolaşıyor, gündüz film seansına gidiyor, radyo dinliyor. Uyumayı seviyor." Filmdeki işsiz flaneur teması, bu karakterin notlarında yeniden karşımıza çıkmaktadır. Aynı zamanda karakterin piyasa toplumsallığının beğenmediği ve piyasa toplumsallığı için üretici olmayan tüm etkinlikleri yaptığı ve bunları yapabilmek için çalışma saatlerini en aza indirecek işi aradığını öğrenmekteyiz. Veblen Aylak Sınıfın Teorisi kitabında burjuva sınıfını oluşturan özelliklerden birinin boş zaman mülkiyeti olduğunu söylemektedir (Veblen, 2005). Onun için ancak sınıflı toplumda üretim araçlarını elinde bulunduranlar böyle bir imkâna sahiptir. $\mathrm{O}$ halde günlerini çalışarak geçirenler için bir lüks olarak kabul edilen boş zaman mülkiyeti, bu kavram etrafındaki imgeler ile piyasa toplumunda çalışma eleştirisinin bir boyutunu oluşturmaktadır. Bu çerçevede karakterin boş zamanla yapabileceği tüm aktiviteler ile zamanını ve emeğini bir başkasına belli bir ücret karşılığı kiralamak arasında bir tercih yaptığını söylemek mümkündür. Karakterin sinemaya ve tiyatroya gidebilmeyi, kitap okuyabilmeyi ve fiziksel olarak dinlenmeyi tercih etmesi Maleviç' in "hem sanatta hem de dinlenmede özel bir çeşit tembellik gizlidir" (Maleviç, 2015: 20-21) saptamasını hatırlatmaktadır. Öte yandan insan yabancılaşmış çalışmayla ulaşamayacağı entelektüel farkındalıklara, sanat ve dinlenme yoluyla ulaşmaktadır. Karakterin kendi hikâyesini anlatmak için tasarladığı foto-roman, boş zaman ve sanatsal yaratıcılık arasındaki ilişkiyi yansıtmaktadır.

Kamera yine yürüyen bir karakteri takip etmektedir. Yürümek, filmdeki flaneur, aylak karakterlerin, fikirlerden fikirlere atlayışlarının bedensel bir ritmi olarak temsil edilmektedir. Çünkü telaşsız yürüyüşler şehrin akıp giden hızından belli parçalar yakalamak ve bunlar hakkında düşünmek imkânı vermektedir. James Joyce'un Ulysses ${ }^{1}$ romanı da tek bir kişinin şehri yürüyerek dolaşırken oluşturduğu gözlemlerini anlatarak, sanatsal yapıtlardaki yürümek ve fikir üretmek ilişkisini örneklemektedir. David Johnson, filmin Joyce'un ad1 geçen romanıla bir akrabalık ilişkisinde olduğunu ifade etmektedir (Johnson, 2012: 6). Aynı şekilde Dobbins, İrlanda edebiyatı içindeki aylak karakterleri incelediği çalışmasında, James Joyce'un eserlerinde de aylaklığın bir olgu olarak görüldüğünü ve bu nedenle anti-kapitalist bir yönü olduğunu vurgulamaktadır (Dobbins, 2010: 64). Öte yandan Deleuze ve Guattari geofelsefe kavramında bir düşünme etkinliği olarak felsefenin "ortam, dost, görüş” (Deleuze

1 Modern edebiyatın en önemli örneklerinden olan Ulysess romanı için: James Joyce; Ulysses, Çev: Nevzat Erkmen, Yapı Kredi Yayınları, 17. Basım, 2015, İstanbul. 
ve Guattari, 2013: 87) kavramlarıyla ilişkili olduğunu vurgulamaktadır. Antik Yunan'da bu üç kavramın yan yana gelmesi felsefenin doğuşuna imkân vermiştir. Yürümek ve boş zamana sahip olmak, düşüncenin yeni bir bakış ararken bir halden bir hale gelmesi için gereklidir. Filmdeki karakterler Deleuze'ün ve Guattari'nin Antik Yunan'da felsefenin doğuşunun motivasyonu olan "ortam, dost, görüş" üçlüsünü, durmaksızın değişen mekânlarda, sözün eşitliğine dayalı fikri müzakereler biçimiyle somutlaştırmaktadır.

Bu anda film, birkaç kişinin sohbeti üzerinden, sinemaya gitmek için buluşan bir çifte geçer. Elinde çocuklardan yarı fiyatına aldığı kola ile yürümekte olan çifte, bir dilenci "Hey gelişmekte olan kapitalist gençlik bozuk paranız var mı?" diyerek seslenir. Çiftten kadın olan kolayı dilenciye vermeyi tercih eder. Adam ise "Bu yaptığın yanlış çünkü bunlar ona yardım etmeyecek. Küçümseme ve acıma arasında bir ilişki gelişmeye neden olacak. Birine acıdığında onun potansiyellerini göremezsin. Birine yardım etmek fikri belli bir güçsüzlükten çıkıyor. $\mathrm{Bu}$ senin mükemmelleşmene ve gelişmene engel olmaktadır!" diyerek kadının eylemini eleştirmektedir. Kadın ise adamın bu fikrinin özgün olmadığı kanaatindedir. Adam “Enazından ben senin bağlandığın şu köle ahlakına sahip değilim!” cevabıyla Nietzsche' nin felsefesinden etkilendiğini ortaya koymaktadır. Nietzsche "kişi, acıma duyduğunda, gücünden yitirir. Acıma yoluyla, zaten acı çekmenin kendisinin yaşama getirdiği güç eksilmesi, yoğunlaşır, çeşitlenir. (...)Acıma nihilizmin pratiğidir" demektedir (Nietzsche, 2003: 13-14). Öte yandan 'köle ahlakı' kavramı Bertrand Russell'ın çalışma ideolojisi eleştirisi için kullandığı kavramlardan biridir. Russell'a göre; çalışma faaliyetleri, insanın kişisel gelişimini mümkün kılan boş zamanı ortadan kaldırdığı ve insanları çalışmaya bağımlı kıldığ1 için insanları köleleştirmektedir. Burada Antik Yunan'ın zihin dünyasının izlerini görmek mümkündür. Bu nedenle; çalışma ahlakı "köle ahlakıdır" (Russell, 2013: 13). Çalışma ahlakından kaçınmak ve çalışma sürelerini kısaltmak özgürlük için elzemdir. Bu nedenle Russell'ın çalışma sürelerinin kısaltılmasını olanaklı hale getirecek önerisi, üretimin ve tüketimin dengelenmesidir. Herkesin ancak tükettiği kadar çalışması fikri hem çalışma ideolojisinden kurtulmuş bir toplumu mümkün hale getirecektir hem de kişilere yeterli boş zaman bırakacaktır. Russell (2013: 16) bu konuda,

"Çalışmanin genellikle tatsız bir şey olduğunu kabul edersek, insanın kendi ürettiğinden fazlasını tüketmesi adaletsizliktir. İnsan doğallıkla, mesela hekimlikte olduğu gibi, mal yerine hizmet sağlayabilir, ama ne olursa olsun, yediğine ve başını bir çatı altına sokmasına karşılık bir şey sağlamalıdır. Çalışmanın ancak bu kadarı bir görev sayılmalıdır; ama ancak bu kadarı"

demektedir. Filmin bir sonraki sahnesi çalışma ideolojisi eleştirisini kuramsal olarak tartışmaya devam etmektedir. Otostopla yolculuk yaptığı arabadan inen karakter anket yapmakta olan bir çiftle karşılaşır. Sorulardan ilki adamın en son yapılan genel seçimde oy kullanıp kullanmadığıyla ilgilidir. Adam “Hayır, daha önemsiz işlerim var!” cevabıyla işler ve uğraşlar hiyerarşisini ters yüz etmektedir. İkinci soru olarak sorulan “Geçiminizi sağlamak için ne yapıyorsunuz?" sorusuna ise, "İşi mi kastediyorsun?" “Geçiminizi sağlamak için yapmak zorunda olduğunuz işin canı cehenneme. Tek yaptığı bizi kullanan domuzların karınlarını doyurmak. Bana bak, ben yapmıyorum. Kötü bir şekilde yaşıyor olabilirim ama en azından yaşamak için yapacak şeyim yok!" yanıtını verir. Polanyi, başta emek olmak üzere, toprak gibi temel üretim güçlerinin satılır hale gelmesinin piyasa toplumunda olduğunu söylemektedir (Polanyi, 2013: 119- 121). Bu nedenle sadece piyasa ekonomisine dayalı bir toplumda temel gereksinimler için çalışmak bir zorunluluk halini almıştır. Karakterin verdiği yanıt temel gereksinimler için çalışmayı zorunlu hale getiren piyasa ekonomisine dayalı sınıflı 
toplumun tarihini yansıtmaktadır. Anketi yapanlar, karakterle mülakata devam ederek "Bir iş bulmanıza ne vesile olabilir?" sorusunu sorarlar. Adam "Gerçek çağrıyı duyduğumda iş bulacağım!" cevabını vermektedir. Sonra mülakatı yapanların kamerasına dönerek "İşçilere sesleniyorum: ürettiğiniz her bir parça ölümünüzün bir parçası!" Bu ifade bir kez daha Marx ve Lafargue'ı hatırlamamıza yol açmaktadır. Marx yabancılaşmış çalışma içinde insanın türsel olarak yok olduğunu yazmıştır. Lafargue ise çalışmayı üretim paradigmasına dayalı sistemin devam etmesine yol açtığı için eleştirmektedir.

Hikâye bir başka tuhaf karaktere kayar. Televizyon dolu bir oda içinde bir adam elinde kumandasıyla görünmektedir. Bu adamın sırtına açık bir televizyon bağlanmıştır. Karakter elektronik imajlarla kurulan bir gerçekliğin eleştirisini temsil etmektedir. Kendi teorisini şu şekilde açıklamaktadır: "Gerçek bir görüntüdense video görüntüsü çok daha gerçektir. En son dışarı çıktığımda bir adam bardan dışarı sırtında bıçakla düştü. Bu olayı geri saramam, duraklatamam ve ayrıntılarına bakamam. Kan bile gerçek kan gibi değildi. Renk tonu bile doğru değildi. Bana gerçek gibi gelmedi!” Televizyondaki işlenmiş ve kurgulanmış dünyanın gerçekliğiyle muhatap olan karakter için artık kurgulanmamış ve işlenmemiş gerçek, kötü bir kopya haline gelmiştir. Bu çerçevede, çalışma ideolojisini radikal bir sistem eleştirisi üzerinden yapan Jean Baudrillard'ın "ekrana baktığımızda doğrudan sanal görüntü evrenine yerleşiyoruz. Ekrandaki görüntünün içine sanki yaşamın içine girercesine dalıyoruz. Yaşantımızı üstümüze bir tür dijital tulum gibi geçiriyoruz" (Baudrillard, 2012: 71) sözlerini anmak gerekmektedir. Gerçekliğin oluşturulmasında ve piyasa toplumsallı̆̆ının yeniden üretilmesinde televizyon, önemli bir kitle iletişim aracıdır. Teknolojik ortamda oluşturulan imajlar yoluyla toplumsal hayatın somut gerçekliği örtülür ve ona yön verilir. Bu noktada gerçeklik ile sanalın yer değiştirmesi piyasa ekonomisiyle ihtiyaçlara dayalı ekonominin yer değiştirmesinde görülen etkiyi yaratmaktadır. Bireyler kendilerinden başlayarak tüm toplumsal olaylara ve olgulara yabancılaşmaktadır.

Film birkaç 'tuhaf' karakterin yaşam ve kültür üzerine görüşlerini yansıttıktan sonra filmi çeken kameranın, yolculuk yapmakta olan genç bir grubun öznel çekimlerine geçmesiyle sona yaklaşır. Anlatım biçimi, karakterler ve karakterlerin tartıştıkları meseleler ticari sinemada sıkça izlediğimiz kamusal yaşam temsilinden farklı bir kamusal yaşamı kurmaktadır. Filmdeki kamusal alanlar Sehla Benhabib'in "agonistik" (Benhabib, 96: 238) ifadesiyle H. Arendt'in kamusal alan kavramından hareket ettiği ya da Weintraub'un Cumhuriyetçi erdem modeli olarak sunduğu kamusal alanla benzerlikler taşımaktadır. Her iki kamusal alan kavramsallaştırması da Antik Yunan'ın kamusal alanından doğar. Bu kamusal alanda ekonomi gibi zorunlulukların belirleniminden kurtulmuş, çalışma etkinlikleri tarafından kuşatılmamış yurttaşlar, öz yaşamlarının biyolojik sınırlılıklarını düşünsel etkinlikler yoluyla aşmaya çabalarlar.

\section{Sonuç}

Uyuşuk aylaklık, boş zaman ve kamusal alan olgularının Antik Yunan perspektifinden oluşturulduğu bir filmdir. Antik Yunan'da özellikle M.Ö. V. yüzyıldan itibaren boş zamana sahip olmak bir erdem olarak algılanan özgürlügün ön koşuludur. Ve ancak özgür insan sitedeki kamusal yaşam etkinliklerinin en önemlisi kabul edilen politika ve felsefe yapma etkinliğini gerçekleştirebilir. Çalışma faaliyetleri ise özellikle çalışmanın başkası için yapılıyor olması durumunda, kişinin boş zamanını elinden alacağından hor görülmüştür. Bu düşünce biçimi modern dünyada tamamen değişerek, yüceltilen ve hor görülen etkinlikler birbirinin 
yerine geçmiştir. Çalışma ve ekonomiye ait etkinlikler, kamusal yaşamın en temel ve en değerli pratikleri olarak kavranmıştır. Entelektüel, sanatsal ve yaratıcı düşünsel faaliyetler, iktisadi üretimin dışında görüldüğ ü için kamusal alanda marjinalleştirilmiştir.

Richard Linklater'ınUyuşuk'unda mekânlarvekarakterleraracılığıyla, Antik Yunan' daki kamusal alana özgü bir perspektif oluşturulmuştur. Film boyunca çoğunluğu kamusal alanda geçen sahnelerde çalışma etkinliğinin zorunluluğu altında olmayan farklı karakterler yer alır. $\mathrm{Bu}$ karakterlerin hepsinin sahip olduğu boş zaman, onlara dünya, toplum ve sanat üzerine düşünme fırsatı tanır. Karakterler birbirleriyle kamusal alanın çeşitli yerlerinde; sokaklarda, kafelerde, parklarda karşılaşıp fikri paylaşımlarda bulunur. Bu karşılaşmalarda kamusal alan Antik Yunan dünyasının agorasına benzer. Karşılaşmalarda ortaya çıkan sohbetler yine Antik Yunan'ın 'ideal' olmaktan uzak tanımladığı ekonomik gereksinimlerin belirleniminde değildir. Çeşitli kuramlar ve kavramlar, bu fikir paylaşımlarının bir parçası olmuştur. Bu noktada karakterler, üretim olgusunu modern dünyadaki ekonomi merkezli yaklaşımdan çıkartıp Antik Yunan'a özgü bir biçimde yeniden düşünmemiz için kapı aralarlar.

\section{Kaynakça}

Applebaum, H. (1992). The Concept of Work: Ancient, Medieval, and Modern (Suny Series in the Anthropology of Work), New York: Sunny.

Arendt, H. (2006). İnsanlık Durumu, çev. Bahadır Sina Şener, İstanbul: İletişim Yay.

Aristoteles (1990). Politika, çev. Mete Tunçay, İstanbul: 1990.

Balme, M. (1984). Attitudes to Work and Leisure in Ancient Greece, GreeceERome, Cambridge University Press, Vol.31, No:2, s:140-152.

Baudrillard, J. (2012). Şeytana Satılan Ruh Ya Da Kötülü̈̆̈̈̈n Egemenliği, çev. Oğuz Adanır, Ankara: Doğu Batı Yay.

Benhabib, S. (1996). Kamu Alanı Modelleri, Cogito, Yaz, Say: 8, ss: 238-259.

Benjamin, W. (2012). Pasajlar, çev: A. Cemal, İstanbul: YKY.

Buğra, A. (2005). İktisatçılar ve İnsanlar Bir Yöntem Çalışması, İstanbul: İletişim Yay.

Deleuze, G. (2009). İki Delilik Rejimi Metinler ve Söyleşiler 1975-1995, çev. Mahir Ender Keskin, İstanbul: Bağlam Yay.

Deleuze, G. (2014). Sinema I Hareket İmge, çev. Soner Özdemir, İstanbul: Norgunk Yay.

Deleuze, G. \& Guattari, F. (2013). Felsefe Nedir?, çev. T. Ilgaz, İstanbul: YKY.

Diken, B. (2011). Nihilizm, çev. Aylin Onacak, İstanbul:Ayrıntı Yay.

Dobbins, G. (2010). Lazy Idle Schemers, Irish Modernism and The Cultural Politics of Idleness, Dublin 2: FieldDay Publications.

Frazer, N. (2004). Kamusal Alanı Yeniden Düşünmek: Gerçekte Varolan Demokrasinin Eleştirisine Bir Katkı. Meral Özbek (Ed.),Kamusal Alan içinde (s.103-133). İstanbul: Hil Yay.

Friedell, E. (1999). Antik Yunan'ın Kültür Tarihi, çev. Necati Alça, Ankara: Dost Kitabevi Yay. 
Gürbüz, A. (2014). Filozof ve Yurttaşları ve Zamansal Düzenleme, Özne Felsefe, 21. Kitap, Güz, ss: 197-210.

Habermas, J. (2017). Kamusallı̆̆ın Yapısal Dönüşümü, çev. Mithat Sancar, Tanıl Bora, İstanbul: İletişim.

Hesiodos, (2014). İşler ve Günler Tanrıların Doğuşu, çev. Furkan Akderin, İstanbul: Say Yay.

Johnson, D. T. (2012). Richard Linklater Contemporary Film Directors, Urbana, Chicago, Springfield: University of Illinois Press.

Ken, R. (2014). Sociology of Leisure and The Wars of The Lifestyle Gurus. Monika Fludernik, Miriam Nandi (Ed.), Idleness, Indolence, and Leisure in English Literature içinde (s. 273-293) England, New York: Palgrave Macmillan.

Lafargue, P. (2014). Tembellik Hakkı, çev. Işık Ergüden, İstanbul: Kırmızı Kedi Yay.

Le Breton, D. (2007). Yürümeye Övgü, çev. İsmail Yerguz, İstanbul: Sel Yay.

Lis, C. (2009). Perception of Work in Classical Antiquity: A Polyphonic Heritage. Catharina Lis, Josef Ehmer (Ed.), The Idea Of Work In Europe From Antiquity To Modern Times içinde (s.33-71) Burlington: Ashgate Publishing Limited.

Maleviç, K. (2015). İnsanın Esas Gerçekliği: Tembellik, çev. Ender Keskin, İstanbul: Sel Yay.

Méda, D. (2012). Emek Kaybolma Yolunda Bir Değer Mi?, çev. Işık Ergüden, İstanbul: İletişim Yay.

Negt, O. \& Kluge, A. (2004). Kamusal Alan ve Tecrübe'ye Giriş. Meral Özbek (Ed.) Kamusal Alan içinde (s.133-141) İstanbul: Hil Yay.

Nietzsche, F. W. (2003). Deccal, çev. Oruç Aruoba, İstanbul: İthaki Yay.

Özbek, M. (2004). Kamusal Alan, İstanbul: Hil Yay.

Öztürk, S. (2018). Sinema Felsefesine Giriş- Film Yapımı Felsefe, Ankara: Ütopya Yay.

Platon (2003). Devlet, çev. Sabahattin Eyüboğlu, M. Ali Cimcöz, İstanbul: Türkiye İş Bankası Kültür Yay.

Polanyi, K. (2013). Büyük Dönüşüm Çağımızın Siyasal ve Ekonomik Kökenleri, çev. Ayşe Buğra, İstanbul: Birikim.

Ranciére, J. (2013). Filozof ve Yoksulları, çev. Aziz Ufuk Kılıç, İstanbul: Metis Yay.

Russell, B. (2013). Aylaklı̆̆a Övgü, çev. Mete Ergin, İstanbul: Cem Yay.

Sennett, R. (2002). Kamusal İnsanın Çöküşü, çev. Abdullah Yılmaz, Serpil Durak, İstanbul: Ayrintı Yay.

Simmel, G. (2000). Öncesizliğin ve Sonrasızlı̆̆ın Işı̆̆ında An Resimleri Felsefi Minyatürler, çev. Alican Taşpınar, Ankara: Dost Yay.

Ste.Croix, G. (2013). Antik Yunan Dünyasında Sınıf Mücadelesi, çev. Çağdaş Sümer, İstanbul: Yordam Kitap. 
Stone, R. (2013). The Cinema Of Richard Linklater: Walk, Don't Run, London, New York: A Wallflower Press, Columbia University Press.

Sylvester, C. (1999). The Classical Idea of Leisure: Cultural Ideal or Class Prejudice?, Leisure Sciences, 21 (1), s: 3-16.

Thomson, G. (1997). Eski Yunan Toplumu Üzerine İncelemeler İlk Filozoflar, çev. Mehmet H. Doğan, İstanbul: Payel Yay.

Veblen, T. (2005). Aylak Sımıfın Teorisi, çev. Zeynep Gültekin, Cumhur Atay, İstanbul: Babil Yay.

\section{Filmler}

Detour Filmproduction (Yapımc1), \& Linklater, R. (Yönetmen). (1991). Slacker [Sinema Filmi]. A.B.D: Stüdyo Yok.

\section{Internet Kaynakçası}

Hang Out (tarihsiz). Cambridge Dictionary Online, http://dictionary. cambridge.org/dictionary/turkish/hang-out [Erişim: 18.01.2015].

Richard Linklater İle Söyleşi, 25.06.2012, Youtube, https:/ / www.youtube.com/ watch?v=T6t_f_aWd_4 [Erişim: 13.01.2015]. 